\title{
Customary Penalty Sanctions for Adultery Crimes in Temon Village, Arjosari District, Pacitan Regency
}

\author{
Arief Budiono \\ Universitas Muhammadiyah Ponorogo \\ ariefbudiono@umpo.ac.id \\ Erlin Reniawati \\ Universitas Muhammadiyah Ponorogo \\ erlinreniawati96@gmail.com \\ Mira Anjar Oktaviani \\ Universitas Muhammadiyah Ponorogo \\ miraanjar29@gmail.com
}

\begin{abstract}
Today, some Indonesian still adhere to the customs that come from their respective regions. It also includes habits that are carried out repeatedly which becomes a rule or commonly referred to customary law. Based on the philosophical aspect of customary law that lives, grows and develops in the soul of the Indonesian people in accordance with the values of the Pancasila as stated in the opening of the 1945 Constitution, the existence of customary law is very influential on customary crimes that occur in certain regions. Customary violations are still commonly found in the community, especially adultery. The implementation of customary criminal sanctions is felt to provide satisfaction and a sense of justice for some people so that the people's lifes can be balanced.
\end{abstract}

Keywords: Customary Law; Adultery Crime; Sanctions

\section{A. INTRODUCTION}

The existence of customary law is still experienced by Indonesian people. It is known that customary law is a form of law that still continues to apply and implement in society. Customary law is a form of law that is neither written nor codified but this has been believed and trusted by most Indonesian people, especially in rural communities. Customary law is a reflection of people's lifes who live in an area so that each region has its own customary law in accordance with their respective regions customs. Although it is not written, the values contained in customary law apply in the lifes of indigenous peoples who utilize these customary laws (Handoko, Effendi, \& Hendra, 2015).

Hilman Hadi Kusuma stated that customary criminal law is a translation of "adat delecten recht" or also referred to as the customary violation law. He also stressed that actually the people did not recognize these terms. However, even 
though the community does not understand the term, it has become inherent and a habit for the community (Hadikusuma, 1979).

One of the crime which occured in the lifes of Indonesian people is adultery. In the community's view the concept of adultery itself is anyone who has sexual intercource without marriage bond, whether just one of them or both. However, this point of view is different compared to the Indonesian Criminal Code (i.e. Kitab Undang-Undang Hukum Pidana [KUHP]) Article 284. In this Article, adultery is sexual intercourse outside the marital status and one of the committer or both of them already have marital ties. It is assumed that they who do not have marital ties before is unconsidered to be criminal. The Indonesian Criminal Code states adultery is categorized as complaint offense, so that an act of adultery can only be prosecuted if one part complains about it. If there are no complaints from the wife or husband of the committer, then they cannot be prosecuted (KUHP clause 284).

The imbalance between the prevailing laws and the events that occur in the community makes a legal vacuum so that the role of customary law that first grows in the midst of the people can be an alternative solution and it might be considered to restore the balance of society.

\section{B. RESEARCH METHOD}

The type of research used in this study is empirical juridical research and descriptive analytical. Empirical research means that the research is photographing or researching laws that live or develop in society and not just the laws written in the regulations. This study has the understanding that the truth can be proven in the realm of reality or can be felt by the five senses and not a fiction (Sonata, 2014).

The research analysied descriptively and it aims are to provide detail, systematic and accurate description of the object based on a fact in certain circumstances. The purpose of describing the results of the study is to complete and gain the detailed data on primary and secondary data (Soekanto, 1996). The data of this study were carried out using various stages: library research and obtaining the data through interview with parties or communities that apply customary criminal sanctions in Temon Village, Arjosari District, Pacitan Regency. Data analysis is done by examining all data from various sources, namely interviews and literature studies. Then the data collected in this study were analyzed using qualitative methods. The data obtained from the literature study and research data are analyzed qualitatively so that it can produce comprehensive research (Manan, 1991).

\section{DISCUSSION AND ANALYSIS}

\section{Existence of Customary Law in the Community}

Customary law is community agreement that have been made as social control of the community. It is useful to harmonize an imbalance which occurs in the 
community. Customary law has existed in the souls of Indonesian society long before colonialism. In Arabic term the customary law is referred to al-'ädah (i.e. a repetitive action), so it assumed that custom is normative habits that has been manifested in the rules of community behavior and maintained by society (Sudaryanto \& Riyanto, 2016).

Customary law grows, develops and applies in the midst of people's lifes, so customary law also develops along with the development of communities. Customary law is always patterned in deliberation and consensus; it means that customary law is born from a community life that upholds the values of togetherness and peace. All correct decisions according to customary law are decisions from the results of deliberation, not a decision based on the personal willingness of a leader. Additionally, resolving a customary violation is also resolved together by deliberation and consensus.

Customary law has links to several aspects, namely religious aspects and cultural aspects. Its relation to the religious means that the community accepts the influence of religious teachings, so their customs are based on their religion believe. The theory was stated by Van Den Berg, namely Reception in Complexu which means full acceptance theory. This means that people accepts the whole religious law that applies and adopted by them. According to this understanding, customary law adheres to a system of practices or ideas, actions, results of actions that are recognized to be habits by going through the process of learning from generation to generation (Hakim, 2017).

Bushar Muhammad also explained that in all legal systems that exist in other parts of the world, customary law always grows from a real necessity. The way and view of life as a whole is the culture of the community where customary law applies. The description can be interpreted that customary law is a reflection of the nature as character and personality of the people (Apriani, 2015).

The Indonesian has recognized the existence of customary law which stipulated in the 1945 Constitution Article 18B clause (2):

"The Country acknowledge and adhere the entity of people's customary law including their traditional rights, as long as it lives and corresponds with community development and the principles of Republic of Indonesia that regulated by the law"

Customary law in community can be carried out in condition that it does not has conflict or clash with the existing written law. This happens in such way because the function of customary law itself is as community's shield from violation. Customary law which is an inheritance law from the ancestors has its own role for the community. This custom always related to the people's thoughts and the local community's experiences. Despite the fact that the community itself does not really understand what is said as custom or customary law, but the community has 
believed that if they break this custom, they will get sanctions, which basically in form of an agreement of the local community (Apriani, 2015).

According to M. Kosnoe, the concepts between Western law and customary law have some differences. In Western law, individual is seen as free individual and has their own interests. Each individual will endeavor to fulfill his/her desire. So, the sanctions existed as guarantee to prevent violations. This is different from the concept of customary law which states that individuals ia a part of society and has strong togetherness and communal nature (Susylawati, 2009). This difference concept affects the sanctions applied in customary law. Actually the sanctions applied in this customary law are not a very urgent matter because this sanction is an attempt to restore the disturbed balance in the community due to a violation committed by someone. If the balance has been restored, there will be no problems.

The customary law in particular community always considers itself to be an integrated part of the universe. Whereas the most important is how to create harmonious and balanced laws as well as creating harmonious relationship between humans and the environment. The essence of conceptual law enforcement lies in the harmonizing the relationships of values contained in rules and apply them in order to create and maintain the peace of community's life (Safrijal, 2013).

Customary law is chosen as a reference in resolving problems that might occur in people's lifes because customary law is deemed not to conflict with the wishes of the community. The source of customary law itself came from the community. The relationship between legal existence and effectiveness is legal and it can be interpreted that the law can achieve its objectives and meanings which really apply in function (Soekanto, 1996).

Furthermore, the existence of law can be seen if the applied law is really serve benefits to the people who implement it. Customary law is a part of law originating from community's experiences in the form of social rules which are made and maintained by legal functionaries and used to regulate legal relations in society.

Article 28I clause 3 states "traditional identity and traditional community rights are respected inline with culture development". This article is the juridical basis for the acknowledgment of customary law in Indonesia. While the enactment of customary law sociologically applied, customary law grows in the community so that customary law applies in the community because of the willingness and coercion of the community itself. Moerover, the rights and obligations can be fulfilled in accordance with the principles of justice (Subari, 2010).

Although customary law system generally only applies to certain communities, this is clearly different from the written law which has the power to apply nationally. In fact, this customary law or unwritten law is being the soul of the 
Indonesian people. According to Hermien H. Koeswadji, people's compliance with the provisions of this unwritten customary law has inspired the whole community's life as manifestation of good citizenship. Even though the rules contained in customary law are not written down, the rules are inherent in the soul of the Indonesian people, in another sense this has become an embedded belief since the existence of mankind, because customary law is a legacy or inheritance from ancestors of Indonesian society (Christianto, 2012).

\section{Implementation of Indigenous Criminal Sanctions}

Adat delicten recht or commonly referred to as customary law is derived from the values contained in society which aims to providing balance in community life. The community provides sanctions that have been mutually agreed upon against offenders in the application of these rules (Ridoi, Erdianto, \& Diana, 2016).

A custom offense that oftenly found in the lives of indigenous peoples is related to the crime of adultery. The concept of adultery according to Indonesian society in general is an act carried out by two people of the opposite sex, then having sexual intercourse outside of a legitimate marriage bond.

Customary law is strongly opposed for anyone who has sex outside the marriage bond is an act of adultery, regardless of whether the person has a marriage bond with another person or not. In contrast to what is meant by criminal acts of adultery in the Criminal Code, an act is said to be a criminal act of adultery if it is carried out by one of the parties who have a marriage bond with another party. If both of them are not bound by marriage, this is not considered an illegal act. In addition, the Criminal Procedure Code also states that adultery is an absolute complaint offense so that even though adultery has occurred, the offenders of the act cannot be criminalized, except for complaints from her husband or his wife who feel that they have been harmed by their act (Upara, 2014).

Basically the Indonesian still uphold moral values, such actions (adultery) for most Indonesian people are considered as immoral acts, whereas in the Criminal Code these acts are not considered as a criminal offense if one party or both are not married. This understanding (Indonesian Criminal Code) is still in line with the individualist mindset of society who considers adultery as an ordinary act because it depends on each individual and it is in the individual right to do it (Andriasari, 2011).

The Indonesian Criminal Law itself adheres to the principle of formal legality as stipulated in Article 1 of the Criminal Code, which states that there is no action that can be punished except by the strength of criminal rule in the existing legislation. As a result of this legality principle, in determining a criminal offense it is not permissible to use analogous or interpretations. Thus, the adultery action occured in the community, which viewed as criminal offense by society, is not a 
criminal act based on the Indonesian Criminal Code. That is because there is no regulation in the code which include the non-marriage person being sanctioned for his/her adultery act (Tijow, 2015).

In contrast to the applicable positive law, customary law does not recognize the name of the formal legality principle. So, any act that considered rebellious to order, security, and propriety influences the balance of people's lifes. It also can be considered as customary offense. The provisions of customary law are open to events that might occur. This is because what is used as the basis for determining customary law is a sense of justice and community legal awareness.

Customary law acts as a solution to imbalances that occur in the community. The difference in understanding between the applicable rules and the habits and values that live in the community makes the local community choose another solution to the problems in their village by giving sanctions for adultery act based on their customary law. The feeling of dissatisfaction is in order to maintain the balance of the environment of many people who break the existing regulations. In contrast, people in Temon Village, Arjosari Subdistrict, Pacitan Regency have their own ways to overcome a violation of law that occurs in their environment, especially against the committers of adultery acts.

In Temon Village there have been several cases of adultery that were found and known by local residents. Initially the community only gave sanctions by marrying the party who committed the adultery. Based on the results of the interview with Mr. Riono as the head of the society in Temon village, he said that:

"The case occurred first time by one of the villagers with someone in another village. It was known that they were alone in a woman's house. The man often went to the woman's house and even had overnight until the residents decided to go to the house and bring both of them to my house. Then they were interrogated by residents and village officials. So finally, we decided to wed them to cover up the disgrace done by their act".

This explanation was strengthened by the explanation of Ms. Jamiyatin as the Head of Temon Village who explained:

"Factually, this case of adultery has been repeated several times so that the community deliberates to increase the sanctions. In the past the sanction is to wed the two committers. When another act happened again, the community agreed to add the sanction by paying a fine in the form of building material, such as cement or sand. We hope that this sanctions provide deterrent effect for the offenders and prevent there are no more similar incidents happened."

Based on the results of the interview, it can be concluded that the adultery criminal sanction in Temon Village, Arjosari Subdistrict, is using the concept of deliberation of village officials, religious leaders and the community which resulted in agreement to raid the residents who were considered for having adultery. After the raid, the offenders then interrogated for their actions. Founding guilty of their 
crime based on the evidences they were subjected to sanctions agreed upon by the surrounding community.

The agreement made by the village community is a form of law that was born from the legal needs and feelings of the Indonesian people. Then, it is able to answer legal problems in everyday life, because in fact the community has its own autonomy towards its legal values (Maladi, 2010).

\section{CONCLUSION}

Customary law is a community agreement that is made as a social control of the community and used to reconcile an imbalance that occurs in the community. Customary law is always patterned in deliberation and consensus, it means that customary law is born from a community life that upholds the values of togetherness and peace. These rules are derived from the values contained in society with the aim of providing balance in community life.

Based on the research that the author did, the village of Temon Arjosari District applies a community agreement on the crime of adultery that occurred in the village. The prevailing provision is that if it is known by the local community that someone commits adultery, the sanctions will be given in the form of giving some material such as cement or sand. This matter has become a community agreement to provide a deterrent effect for the perpetrators.

\section{REFERENCES}

Andriasari, D. (2011). Studi Komparatif Tentang Zina dalam Hukum Indonesia dan Hukum Turki. Syiar Hukum, 13(3), 265-279.

Apriani, D. (2015). Urgensi Hukum Adat dalam Pembaharuan Hukum Pidana di Indonesia. Jurnal Ilmu Hukum, 5(1), 1-17.

Christianto, H. (2012). Penemuan Hukum Dalam Perkara Pidana Adat. Jurnal Hukum Dan Pembangunan, 42(2), 272-285.

Hadikusuma, H. (1979). Hukum Pidana Adat. Bandung: Alumni.

Hakim, N. (2017). Konflik Antara Al-'Urf (Hukum Adat) dan Hukum Islam di Indonesia. Jurnal EduTech, 3(2), 54-63.

Handoko, B., Effendi, E., \& Hendra, R. (2015). Penerapan Sanksi Pidana Adat Terhadap pelaku zina di Wilayah Kenagarian Garagahan Kecamatan Lubuk Basung Kabupaten Agam. Jurnal Online Mahasiswa Fakultas Hukum, 2(2), 1-16.

Maladi, Y. (2010). Eksistensi Hukum Adat dalam Konstitusi Negara Pasca Amandemen. Mimbar Hukum, 22(3), 450-464.

Manan, B. (1991). Menulis Laporan Penelitian. Bogor.

Ridoi, M., Erdianto, \& Diana, L. (2016). Penerapan Pidana Adat dan Pidana KUHP Terhadap Pelaku Tindak Pidana Zina Dikaitkan Dengan Peran Kepolisian" (Studi Kasus Wilayah Hukum Persukuan Domo Air Tiris dan Kapolres Kampar). Jurnal Online Mahasiswa Fakultas Hukum, 3(2), 1-15.

Safrijal, A. (2013). Penerapan Sanksi Adat Dalam Penyelesaian Perkara Pidana Di Kabupaten Nagan Raya. Kanun Jurnal Ilmu Hukum, 15(1), 1-33.

Soekanto, S. (1996). Pengantar Penelitian Hukum. Jakarta: UI Press.

Sonata, D. L. (2014). Metode Penelitian Hukum Normatif dan Empiris: Karakteristik 
Khas dari Metode Meneliti Hukum. Fiat Justisia Jurnal Ilmu Hukum, 8(1), 15-35.

Subari, A. S. (2010). Pokok-Pokok Hukum Adat (2nd ed.). Palembang: Universitas Sriwijaya.

Sudaryanto, A., \& Riyanto, S. (2016). Eksistensi Delik Adat Di Lingkungan Masyarakat Sentolo, Kabupaten Kulonprogo Yogyakarta, 28(1), 46-60.

Susylawati, E. (2009). Eksistensi Hukum Adat Dalam Sistem Hukum Di Indonesia. AlIhkam: Jurnal Hukum \& Pranata Sosial, 4(1), 124-140.

Tijow, L. M. (2015). Dekontruksi Makna Perzinahan Pada Pasal 284 Kitab Undangundang Hukum Pidana (KUHP) Dalam Realitas social Masyarakat. Jurnal Hukum Legalitas, 8(1), 175-197.

Upara, A. R. (2014). Penerapan Sanksi Pidana Adat Terhadap Pelaku Tindak Pidana Zina Ditinjau dari Hukum Pidana Adat dan Hukum Pidana Nasional Pada Masyarakat Adat Tobati di Jayapura. Legal Pluralism, 4(2), 143-164. 